\title{
Caddo Ceramics from the D'Ortolan Site (41NA299)
}

Timothy K. Perttula

Heritage Research Center, Stephen F. Austin State University

Follow this and additional works at: https://scholarworks.sfasu.edu/ita

Part of the American Material Culture Commons, Archaeological Anthropology Commons, Environmental Studies Commons, Other American Studies Commons, Other Arts and Humanities Commons, Other History of Art, Architecture, and Archaeology Commons, and the United States History Commons

Tell us how this article helped you.

This Article is brought to you for free and open access by the Center for Regional Heritage Research at SFA ScholarWorks. It has been accepted for inclusion in Index of Texas Archaeology: Open Access Gray Literature from the Lone Star State by an authorized editor of SFA ScholarWorks. For more information, please contact cdsscholarworks@sfasu.edu. 


\section{Caddo Ceramics from the D'Ortolan Site (41NA299)}

Creative Commons License

(c) (i) (8)

This work is licensed under a Creative Commons Attribution-NonCommercial 4.0 International License 


\title{
Caddo Ceramics from the D'Ortolan Site (41NA299)
}

\author{
Timothy K. Perttula
}

The D'Ortolan site (41NA299) is a latc 1790s to 1830 s ranch established by Bernard D'Ortolan on Bayou Loco, a tributary to the Angelina River, in Nacogdoches County, Texas. The ranch was known as Rancho San Bernando del Loco. Tom Middlebrook, Texas Archeological Steward, located and identified the rancho in 2003.

During the coursc of archaeological investigations conducted at the site over the next few ycars, a small sample of aboriginal Caddo ceramic sherds wcre found on the rancho in contexts indicating that Caddo ceramic vessels were in use during the rancho occupation. These vessels had to have becn obtained by the D'Ortolan ranch through purchase or trade from one of the Caddo groups living in the Angelina River valley after the 1790 s. The sherds from the D'Ortolan sitc, along with those from 2007 excavations by Tom Middlebrook in the Plaza Principal in Nacogdoches, must represent some of the latest aboriginal Caddo ceramic wares currently known in East Texas.

\section{CHARACTER OF THE CERAMIC ASSEMBLAGE}

A total of 24 Caddo sherds have been recovered to date at the D'Ortolan site (Appendix 1). This includes two rims and 22 body sherds from a general surface collection, two shovel tests, and excavations within Structure 1, the main rancho structure.

Three of the sherds, all from Structure I, arc decorated. These include a jar rim with horizontal brushing (Figure lb) and two body sherds with opposed brushing marks (Figurc 1a, c). This is not particularly surprising since utility ware vessels covered with brushing marks on the rim and/or body are by far the most common form of vesscl decoration in many historic Caddo sites in the Angelina River basin (see Middlebrook 2007; Perttula 2007a), cspecially those of Caddo groups living in the Bayou Loco valley.
Another characteristic of the Caddo ceramics from the D'Ortolan site is the use of bone temper in vessel manufacture. Approximately $79 \%$ of the sherds from the sitc have bone temper. A comparable use of bone temper has also been documented in the Caddo ceramics recovered at $41 \mathrm{NA} 223$, possibly the site of the 1804 mission church Guadalupe del Pilar in downtown Nacogdoches (Perttula 2007b). At the slightly older, ca. 1730-1760, Caddo occupation at the Mayhew site (41N21) on Bayou Loco (see Kenmotsu 1992), bonetempered Caddo vesscl sherds account for $80 \%$ of the large sherd assemblage (Perttula 2007a:Table 1), which also is dominated by brushed pottery vessels.

Another $12.6 \%$ of the D'Ortolan site sherds are grog-tempered, and $8.3 \%$ appear to be shelltempcred; in these sherds (from ST 14), the shell temper has been lcached away. Neither the few grog- or shell-tempered sherds have decorations. Shell-tempered Caddo pottery, very rare in East Texas Caddo sites, is also present at 41NA223, accounting for $5 \%$ of the small assemblage of Caddo sherds from that site (Perttula 2007b). Earlier $18^{\text {th }}$ century Caddo sites in the Bayou Loco area-such as Deshazo (41NA27)-have ceramic assemblages with primarily grog-tempered vessel sherds, but again dominated by brushed vessel sherd decorations.

\section{CONCLUSIONS}

The D'Ortolan site Caddo ceramics indicate that during the last days of the $18^{\text {th }}$ century and the first quarter of the $19^{\text {th }}$ ccntury, Caddo groups living in the Nacogdoches area made bone-tempered brushed utility ware ceramic vessels as wcll as vessels (of uncertain decoration) tcmpered with grog and mussel shell. Examples of these vessels have been rccovered at this historic rancho, providing a tangible record of interaction and contact between the Caddo living in the Angelina River basin and the area's more recent Europcan settlers. 


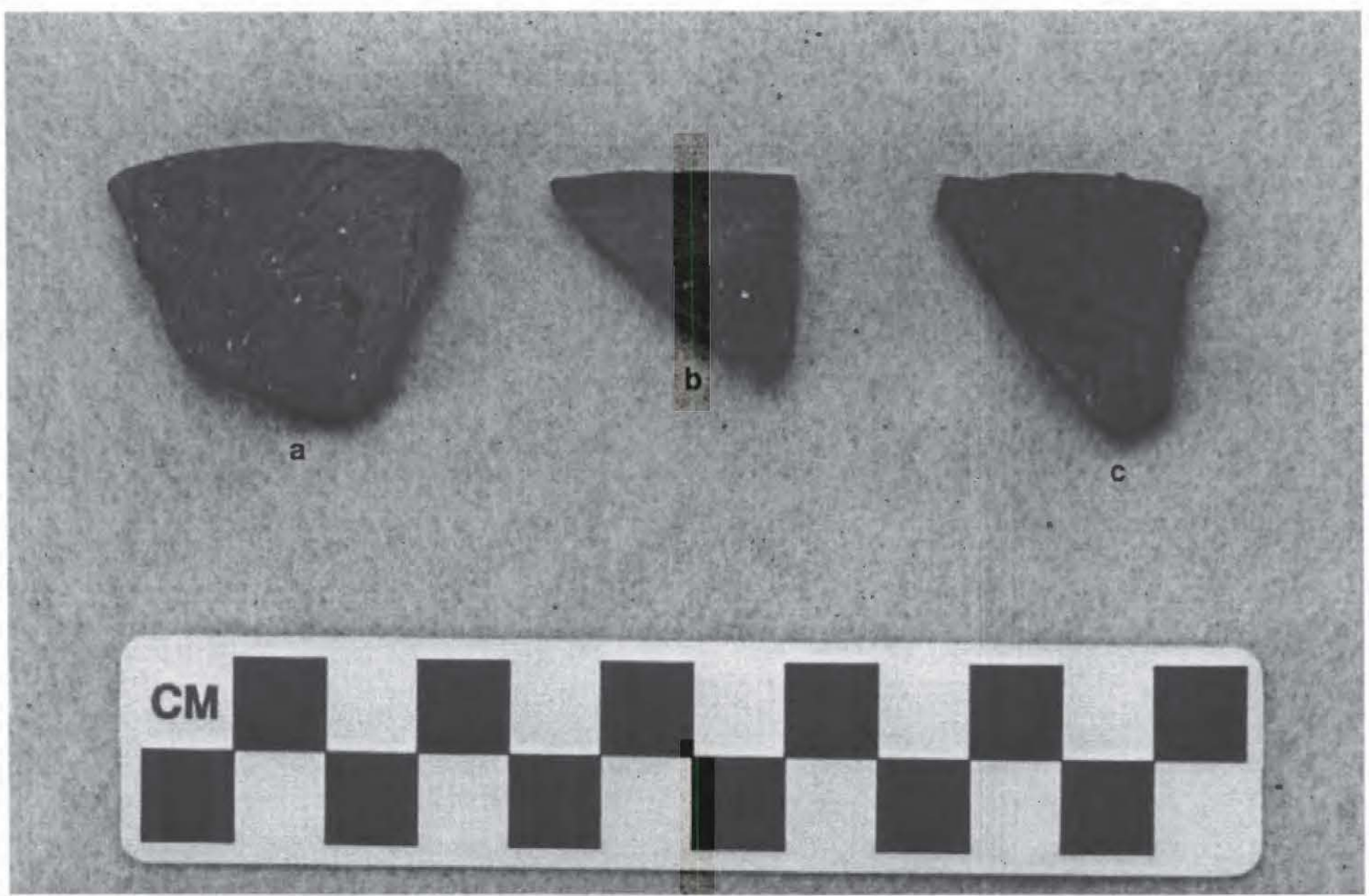

Figure 1. Decorated sherds from the D'Ortolan site (41NA299): a, c, opposed brushed body sherds; b, horizontal brushed rim.

\section{REFERENCES CITED}

Kenmotsu, N. A.

1992 The Mayhew Site: A Possible Hasinai Farmstead, Nacogdoches County, Texas. Bulletin of the Texas Archeological Society 63:135-174.

Middlebrook, T.

2007 A Survey of Historic Caddo Sites in Nacogdoches County. Journal of Northeast Texas Archaeology 26:99-115.
Perttula, T. K.

2007a One Attempt at Defining Allen Phase Ceramic Subclusters. Journal of Northeast Texas Archaeology 26:77-81.

2007b Analysis of the Historic Caddo Ceramics from 41NA223 in downtown Nacogdoches, Nacogdoches County, Texas. MS on file, Archeological \& Environmental Consultants, LLC, Austin. 


\section{APPENDIX 1, INVENTORY OF SHERDS}

General Surface,

No provenience

4 plain body sherds, bone-tempered; 1 plain rim sherd, grog and hematite-tempercd

ST $14,0-5 \mathrm{~cm}$ 1 plain body sherd, possible shell temper; firing conditions (B, fircd and cooled in a reducing or low oxygen environment). $5.7 \mathrm{~mm}$ thick

ST 14, $5-10 \mathrm{~cm} \quad 1$ plain body sherd, possible shell tempcr; firing conditions (B; fired and coolcd in a reducing or low oxygen environment); $5.7 \mathrm{~mm}$ thick

ST $18,0-5 \mathrm{~cm} \quad 1$ plain grog-tcmpered/sandy paste body sherd; firing conditions ( $\mathrm{F}$; fired in a reducing environment, but cooled in the open air); $4.4 \mathrm{~mm}$ thick

Structure 1,

1 plain body sherd, bone-tempered

$1 \times 1 \mathrm{~m}$ unit

Structure 1, N 105

W $102,0-10 \mathrm{~cm}$

11 plain body sherds, bonc-tempered; 1 plain body sherd, grog-tempered; 1 rim sherd, horizontal brushed, bone-tempered; direct rim and flat lip; 2 body sherds, opposed brushing, bone-tempered 